\title{
$\mathrm{D} . \mathrm{a} . \mathrm{m} \quad \begin{aligned} & \text { Documents d'archéologie méridionale } \\ & \text { Protohistoire du Sud de la France }\end{aligned}$
}

$25 \mid 2002$

Varia

\section{Présentation de la Chronique de Protohistoire européenne}

La sculpture préromaine

\section{(2) OpenEdition \\ Journals}

\section{Édition électronique}

URL : https://journals.openedition.org/dam/1173

DOI : $10.4000 /$ dam. 1173

ISSN : $1955-2432$

\section{Éditeur}

ADAM éditions

\section{Édition imprimée}

Date de publication : 20 août 2002

Pagination : 245

ISBN : 2-908774-15-1

ISSN : 0184-1068

\section{Référence électronique}

"Présentation de la Chronique de Protohistoire européenne », Documents d'archéologie méridionale [En ligne], 25 | 2002, mis en ligne le 17 janvier 2007, consulté le 06 avril 2023. URL : http:// journals.openedition.org/dam/1173; DOI : https://doi.org/10.4000/dam.1173

Ce document a été généré automatiquement le 6 avril 2023.

Tous droits réservés 


\title{
Présentation de la Chronique de Protohistoire européenne
}

\author{
La sculpture préromaine
}

1 La sculpture protohistorique en Europe fait l'objet, depuis peu de temps, d'un regain d'intérêt de la part des archéologues mais aussi des historiens et historiens d'Art. Sans chercher à être exhaustive, cette "Chronique de Protohistoire européenne" regroupe plusieurs bilans complémentaires et novateurs qui contribuent au débat. La genèse des images, des styles et des techniques tout comme l'unité et la pluralité de cet art premier de l'Europe occidentale et centrale, font ici l'objet d'approches croisées. De riches bibliographies complètent la présentation de bilans régionaux et la publication de pièces découvertes ou redécouvertes récemment. Dans la livraison 2003 des Documents d'Archéologie Méridionale seront publiés les actes de la table ronde de Velaux sur la sculpture de Roquepertuse (Bouches-du-Rhône) dans son contexte européen.

2 In recent years European protohistoric sculpture has re-emerged as a subject of interest for archaeologists, as well as historians and art historians. Without attempting an exhaustive analysis, this chronicle of European protohistory brings together several complimentary and innovative reviews, which contribute to the debate. The appearance of the images, styles and techniques as well as the unity and plurality of this first western and central European art form are the subject of an integrated analysis. The comprehensive bibliographies complete the presentation of the regional reviews along with the publication of recently discovered or rediscovered pieces. The 2003 DAM will include the proceedings of the Valaux seminar on the Roquepertuse (Bouches-du-Rhône) and its European context. 
INDEX

Keywords : Europe, Protohistory 